\title{
INTERNAL COMMUNICATION AND EMPLOYEE SATISFACTION IN HOSPITALITY*
}

\author{
Ana Čuić Tanković** \\ Ivana Bilic ${ }^{* * *}$ \\ Iva Brajkovic ${ }^{* * * *}$
}

Received: 12. 4. 2021

Original scientific paper

Accepted: 20. 12. 2021

UDC 005.32:331.101.32

DOI https://doi.org/10.30924/mjcmi.27.1.1

\begin{abstract}
This paper aims to analyze the influence of internal communication on employee satisfaction in the hospitality industry from the viewpoints of communication with superiors and colleagues. The study uses survey data from two hotels with the same quality rating and the same hotel chain. Our results
\end{abstract}

Abstract

\section{INTRODUCTION}

Effective communication is a necessary condition for the successful planning, organization, leadership, and control because it "is the way through which members of an organization share their meaning and agree with others" (Koontz et al. 1980) by using different verbal and nonverbal messages (Antolović and Sviličić, 2016). People have a natural predisposition to communicate and interact with each other (Kraljević and Perkov, 2014). Communication coordinates indicate that both forms of communication positively influence job satisfaction, based on the PLS-SEM method.

Keywords: job satisfaction, communication with superiors, communication with colleagues, hospitality industry

actions across hierarchical levels and directs individuals and teams toward the goals (Borca and Baesa, 2014). Lack of communication represents a disturbance, breaks the workflow, causes delays, and creates interpersonal conflicts. Lunenburg (2010) noted the existence of noise, which may exist in the elements of the communication process, as a critical obstacle in reaching complete clarity of meaning and understanding in communication. Eisenberg, Goodall, and Trethewey (2010) identified four types of

\footnotetext{
* This paper was funded under the project framework ZIP UNIRI of the University of Rijeka, project no. ZIPUNIRI-116-4-19.

** Ana Čuić Tanković, PhD, assistant professor, Faculty of Tourism and Hospitality Management, University of Rijeka Primorska 42, B.O. 97, 51410 Opatija, Croatia, Phone: +385 51294 759, E-mail: anact@fthm.hr

*** Ivana Bilić, $\mathrm{PhD}$, associate professor, Faculty of Economics, Business and Tourism, University of Split, Cvite Fiskovića 5, 21000 Split, Croatia, Phone: +385 21430 785, E-mail: ibilic@efst.hr

**** Iva Brajković, MSc, graduate student, Faculty of Tourism and Hospitality Management, University of Rijeka, Primorska 42, B.O.97, 51410 Opatija, E-mail: iva.brajkovic8@gmail.com
} 


\section{Journal of Contemporary Management Issues}

communication barriers: process, physical, semantic, and psychosocial barriers.

Styles and personality factors are considered essential for communication success, alongside interpersonal communication abilities, as those involve social efforts, directly affecting personal or workplace decisions. Primarily, interpersonal communication skills enable more efficient work: employers look for employees with advanced communication skills because of their ability to interact with competitors, colleagues, and clients (Cushman and Cahn, 1985).

Managers and large companies with inadequate communication waste money and time, while good communication helps them to keep the best employees (Carpenter et al., 2010). Communication among managers and employees can create an atmosphere of happiness and passion about their work, with attitudes that help improve organizational performance (Dasgupta et al., 2012), with a unique link between managerial and communication success (Bovée and Thill, 2012).

The hospitality industry, as the fastest-growing sector worldwide (Politis et al., 2009), relies heavily on employees to achieve consumer-related objectives. In hotels, teams are large and characterized by conflicts (Ingram and Desombre, 1999; Richards et al., 2012). To strengthen their affiliation to the group, customers will become committed to a hotel when they see that people they value have an excellent opinion about their company (Pende, 2013). Effective internal communication is a force that enriches employees' lives and, in turn, helps increase customer satisfaction, profitability, and overall company performance. It is a crucial business function that inspires and harmonizes the entire organization and precedes the perceived trust (Prikshat et al., 2020)

The hospitality sector has significant implications for formal employee involvement and participation (Townsend et al., 2011). These objectives can be very complex, while communication is essential in this under-analyzed and growing industrial setting. Job satisfaction and passion for work are critical to the hospitality industry, where most lower-level employees come into frequent contact with clients. These contacts can convey a message more effectively than any paid advertising or other promotional efforts. Marchington and Suter (2012) underline the importance of first-line managers, who may limit the information for the staff or reduce their contribution to decision making. However, in their research, they found a successful implementation of employee involvement and participation due to encouragement of the information management and communication style.

Although employee satisfaction has been widely analyzed, there is still a need to constantly monitor the impact of various forms of communication on employees' job satisfaction. Surprisingly, regarding the main research subject of this study, there is little new research exploring the impact of internal communication on employee satisfaction. Furthermore, Borca and Baesu (2014) suggest investigating the employees' level of job satisfaction following regular communication activities as an interesting topic for future research. Therefore, this specific research aims to contribute to Human Resource Management, communication theory, and internal marketing by building theoretical and empirical knowledge regarding the role of communication in organizations. 
The paper consists of five sections. After the introduction, the theoretical background is presented in the second section. Research methodology, findings, and conclusions represent the following sections.

\section{LITERATURE REVIEW AND THEORETICAL FRAMEWORK}

\subsection{Internal communication - a critical business function}

Internal communication refers to exchanging and sharing knowledge between employees (Chen and Cheng, 2012). It encompasses all communication processes, enables organizational functioning, connects employees (Gray and Laidlaw, 2002), and brings about competitive advantage (Gomes et al., 2011). Because of its strong strategic orientation, the importance of internal communication goes beyond simple measures to inform the internal public. Employees are considered a key source of customer information and a significant contributor to revisit intentions for a hospitality company (King, 2010). Therefore, de Chernatony et al. (2006) advocate influencing employee behavior through internal communication to achieve employee understanding, acceptance, and internalization.

Internal communication is essential for increasing employee satisfaction and productivity (Cummings et al., 1983), regardless of its formality. Formal communication includes all potential communication channels, including downstream or downlink (Bartle and Griffins, 2001; Miljković and Rijavec, 2002), upward (Bartle and Griffins, 2001), horizontal (Bartle and Griffins, 2001), and lateral (Rossela and Stoica, 2012). Formal communication is needed to regulate organizational functioning regardless of the form used. According to Perinić (2008), employees who rely on formal and official sources sometimes do not receive information on time or are misinformed, while informal communication seems more credible and practical in daily interactions. Informal communication about the business is an independent exchange of information and feelings among people (Lesikar et al. 1993). Informal communication within an enterprise is inevitable because when employees bring their problems to the workplace, this can cause spontaneous behavior. During their interactions, colleagues find they have similar views, opinions, and values; they get to know each other and, ultimately, become friends ( $\mathrm{Al}$ Eslami Kandlousi et al., 2010).

Dasgupta et al. (2012) noted the importance of managers in creating an environment where employees will love to work, who may influence working behavior and direct employees to improve organizational performance. The conversation factor is commonly used in this respect, involving communication with co-workers and other internal and external stakeholders (Yang, 2015). In this author's research, conducted in Taiwan franchising hotel chains, communication channels proved essential in knowledge sharing. Results of a Spanish study provide additional evidence that internal communication predicts the workers' affective commitment towards the organization and that procedural justice mediates this relationship (Gomes et al., 2011).

\subsection{Internal communication and employee satisfaction}

Previous research has extensively analyzed the key drivers of employee satisfaction. Jabeen and Isakovic (2018) found that various organizational factors influence employees' trust in top management 


\section{Journal of Contemporary Management Issues}

and greater career satisfaction. Naim and Lenka (2018) argued that competency development is critical for affective commitment and raises the chances of keeping Generation Y employees. Job flexibility represents a vital ingredient of employee satisfaction, primarily when younger employees are concerned, as Baeza et al. (2018) reported.

On the other hand, job satisfaction in the Chinese context is negatively related to union participation and involvement $(\mathrm{Hu}$ et al., 2018). Plester and Hutchison (2016) studied fun and work engagement concerning employee satisfaction. Their exploratory findings suggest that fun in the workplace can be viewed as a refreshing change that positively impacts employee satisfaction. Tews et al. (2015) examined workplace fun among millennials concerning workplace engagement and found that workplace fun was the most important predictor of workplace engagement. Lahap et al. (2016) examined the impact of internal communication on improving service quality and delivery in the Malaysian hotel industry from internal market orientation. Internal communication is one of the four critical factors to enhance the quality of service and delivery. Tkalac Verčič and Pološki Vokić (2017) proved that satisfaction with internal communication influences employee engagement. Additional evidence that the engagement starts to improve as managers recognize the importance of internal communication (Ruck and Trainor, 2012).

Job satisfaction influences employees' commitment and performance in laborintensive industries, such as tourism and hospitality. Thus, satisfaction is crucial for service quality and productivity, and profitability.
The most influential conceptual paradigm for understanding workplace behaviors is the social exchange theory, based on the central premise that the exchange of resources is a foundation for human interaction (Blau, 1964). Organizational support theory, derived from social exchange theory, explains how organizational support influences employee behavior (Eisenberger et al., 1986). In this way, commitments arise when interdependent parties interact (Saks, 2006).

Further development of ICT and modes of communication among employees and between employees and managers may influence the communication experience. Smartphones and their effects on communication are studied by Obushenkova et al. (2018). Their key findings show that smartphones extend the reach of work for employees and managers to offsite locations and outside of working hours, resulting in the employees' and managers' feeling of pressure to be constantly connected to work, even if this is not expected.

Downs and Hazen (1977) confirmed the connection between employee satisfaction with the workplace and internal communication. Still, they noted that it varies depending on whether the employees are managers or non-managerial employees. Their research suggests that some forms of workplace fun provide a break that positively impacts individual employees, leading to greater engagement in the workplace and at work. Employees experience their work as a form of fun and a particular form of engagement known as flow (Plester and Hutchison, 2014).

Wang's (2012) research of the hotel chain has confirmed that the quality of internal communication has a positive and significant impact on workers' satisfaction in international tourism hotels. While 
studying workers in the Indian manufacturing industry, Dasgupta et al. (2012) realized that higher employee satisfaction with communication fosters a strong emotional bond with organizations, resulting in lower employee absenteeism rates. Steyn, Steyn, and van Rooyen (2011) investigate internal communication in a South African branch office from a two-way symmetrical internal communication model. The results show that effective internal communication and corporate efficiency can be improved through adjustments to corporate culture and the nature of internal communication. Gray and Laidlaw (2002) analyzed parttime employees who are not included in mainstream communication and are less satisfied than full-time employees in an Australian retail organization. Initially, companies did not see employee satisfaction as being very important. However, this began to change rapidly, once employers became aware that employee satisfaction and the company's overall success are closely related. Service organizations know that customer satisfaction and loyalty depend on how first-rate employees deal with clients.
The starting point in a study by RuizAlba et al. (2014) related to the hotel industry is that only satisfied employees can produce happy customers. Moreover, they consider internal marketing orientation and internal communication essential employee satisfaction factors. Employees in the tourism and hospitality industry have the abilities and intentions to drive organizational initiatives, as the industry is labor-intensive and service-based (King, 2010).

According to the theoretical framework, it can be concluded that communication can affect job satisfaction and further empirical evidence is necessary to corroborate this impact. Previous research has not analyzed this connection through the dimensions of internal communication with superiors and colleagues. Based on these considerations, we posit the following hypotheses (Figure 1):

H1: Communication with superiors has a positive effect on job satisfaction.

H2: Communication with colleagues has a positive effect on job satisfaction.

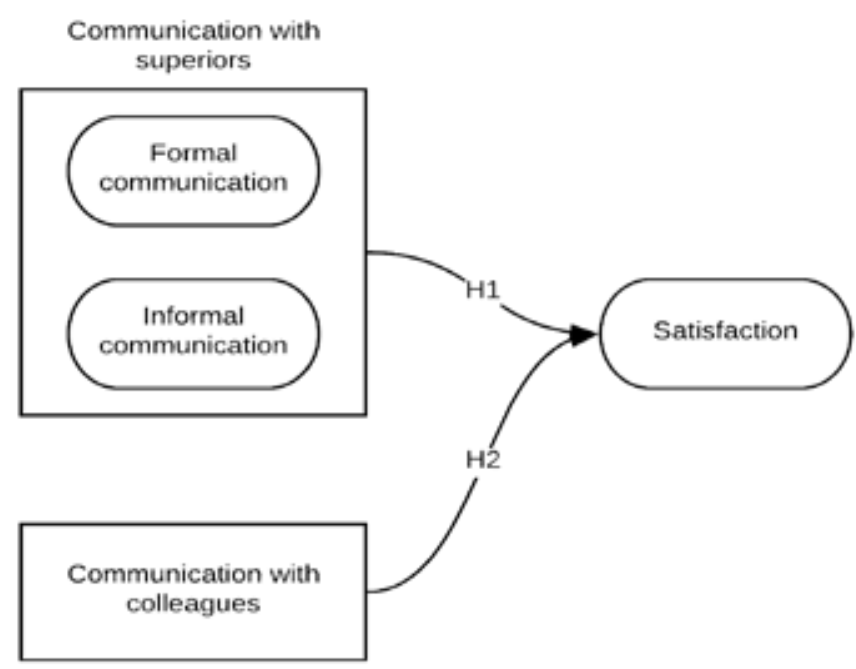

Figure 1. Research model 


\section{Journal of Contemporary Management Issues}

\section{METHODS}

\subsection{Questionnaire design}

This study focused on the employees of hotel facilities using the survey method on a convenient sample. Primary data collection was based on a self-administered questionnaire, consisting of three question blocks, adapted from previous studies (To et al., 2015; Ruiz-Alba et al., 2014; Bolfek et al., 2017; Bamboriki, 2010). The first group of questions explores job satisfaction, the second part is related to formal and informal internal communication with the management, and the last one refers to internal communication with colleagues. The questions in these sections were measured using the 5-point Likert scale, ranging from (1) "strongly disagree" to (5) "strongly agree." The last section of questions centered on sociodemographic characteristics, with close-ended questions regarding the respondents' sex, age, level of education, and the length of time they have been with the current organization.

\subsection{Data collection and sample characteristics}

The hotel industry was chosen as a research area because, although employee satisfaction is crucial for the success of hotel companies, employee turnover and the intention to quit have been identified as significant problems (Silva, 2006; Agušaj and Čuić Tanković, 2016). Another reason is that the hotel industry in Croatia is becoming one of the leading economic sectors in the country, as is the case worldwide (Gržinić, 2008).

In agreement with the hotel management, the employees of two hotels were asked to complete the questionnaire. The hotels will be named Hotel A and B. The relevant context of the selected hotels (Molina-Azorin et al., 2009) is similar: both have the same four-star rating, and their size, measured by the number of rooms, is comparable, as well. Hotel A has 302 rooms and 23 suites, while Hotel $\mathrm{B}$ has 236 rooms and 12 suites. Hotels A and B are also affiliated with the same hotel chain and operate in the same geographical location. In this way, any differences in organizational culture and geographical location would not affect the measured variables. The research sample was selected from the ranks of employees, according to the decision of the hotel management. Data were collected by onsite research. The survey was conducted on a sample of 184 employees, 119 from Hotel A and 65 from Hotel B. The descriptive statistics were computed using IBM SPSS 22, while the PLS-SEM analysis was conducted using the Smart PLS 3.0.

Table 1 indicates the age, sex, education degree, and average time with the organization for the survey participants. Out of the total number of respondents in Hotel A, most respondents are between 31 and 50 $(51.86 \%)$. In Hotel $\mathrm{B}$, the age of most respondents ranges from 22 to $40(54.27 \%)$. The proportion of female respondents was higher than the proportion of male participants in both hotels $(63.41 \%)$. The qualification structure shows a significant dominance of employees with secondary school qualifications, $75.69 \%$ in Hotel A and $61.65 \%$ in Hotel B out of $70.72 \%$ participants who answered this question. The largest group of respondents has been working in Hotel A for 11 to 15 years $(21.36 \%)$, while the employees in Hotel B are much younger: $55.16 \%$ have not been in the organization for more than ten years. 
Table 1. Sample demographic characteristics

\begin{tabular}{|c|c|c|c|c|}
\hline \multicolumn{2}{|c|}{ Measure and item } & $\begin{array}{c}\text { Hotel A } \\
\text { (\% within Hotel A) }\end{array}$ & $\begin{array}{c}\text { Hotel B } \\
\text { (\% within Hotel B) }\end{array}$ & $\begin{array}{c}\text { Cumulative } \\
\text { (\% within Hotel A and B) }\end{array}$ \\
\hline \multirow[t]{6}{*}{ Age } & $18-21$ & 2.78 & 5.08 & 3.66 \\
\hline & $22-30$ & 24.09 & 35.59 & 28.05 \\
\hline & $31-40$ & 25 & 28.82 & 26.22 \\
\hline & $41-50$ & 26.86 & 20.33 & 24.39 \\
\hline & $51-60$ & 21.27 & 10.17 & 17.68 \\
\hline & 61 and over & 0 & 0 & 0 \\
\hline \multirow[t]{2}{*}{ Gender } & Female & 58.5 & 72.88 & 63.41 \\
\hline & Male & 41.5 & 27.12 & 36.59 \\
\hline \multirow{5}{*}{$\begin{array}{l}\text { Educational } \\
\text { level }\end{array}$} & Elementary school & 13.46 & 3.33 & 9.76 \\
\hline & $\begin{array}{l}\text { Secondary } \\
\text { qualifications }\end{array}$ & 75.96 & 61.67 & 70.72 \\
\hline & $\begin{array}{l}\text { Two-year post- } \\
\text { secondary/bachelor's } \\
\text { qualification }\end{array}$ & 5.77 & 16.67 & 9.76 \\
\hline & $\begin{array}{l}\text { Higher education/ } \\
\text { master's } \\
\text { qualifications }\end{array}$ & 4.81 & 18.33 & 9.76 \\
\hline & MBAs, MScs, PhDs & 0 & 0 & 00 \\
\hline \multirow{6}{*}{$\begin{array}{l}\text { Average } \\
\text { years spent } \\
\text { in the } \\
\text { company }\end{array}$} & Up to 5 years & 18.45 & 27.58 & 21.87 \\
\hline & 5 to 10 years & 15.53 & 27.58 & 18.75 \\
\hline & 11 to 15 years & 21.36 & 13.79 & 18.75 \\
\hline & 16 to 20 years & 19.42 & 12.09 & 16.88 \\
\hline & 21 to 25 years & 13.59 & 13.79 & 13.75 \\
\hline & More than 25 years & 11.65 & 5.17 & 9.37 \\
\hline
\end{tabular}

\subsection{Results}

Structural equation modeling, using partial least squares (PLS-SEM), was used in this study. This is a non-parametric method that allows different relationships between constructs even in small samples (Reinartz et al., 2009). A comprehensive model of the relationships between communication with the superiors and colleagues that influence employee satisfaction was designed as a first-order reflective model (or outwards direct model). The reflective indicators can be considered mutually interchangeable without compromising content validity (Jarvis et al., 2003).

Before analyzing the structural model, the evaluation of the measurement model was conducted. All manifest variables were checked for outliers to ensure the reliability and validity of the measurement scales. No variable has a standard deviation value greater than +/-3 from the arithmetic mean in this model. The proposed measurement model describes the relationship between the constructs and is assessed by examining internal consistency (Composite Reliability 


\section{Journal of Contemporary Management Issues}

- CR and Cronbach's alpha coefficient), convergent validity with the average variance extracted (AVE), and factor loadings.

Table 2. Measurement model analysis

\begin{tabular}{|c|c|c|c|}
\hline Item & Outer loadings & Standard Error & t-value \\
\hline \multicolumn{4}{|l|}{$\begin{array}{l}\text { Formal communication with superiors } \\
\text { Cronbach Alpha 0.866; C.R. 0.904; AVE } 0.653\end{array}$} \\
\hline $\begin{array}{l}\text { The company has regular staff appraisals where people } \\
\text { discuss what the employees want. }\end{array}$ & 0.707 & 0.055 & 12.197 \\
\hline $\begin{array}{l}\text { Managers interact formally and directly with employees to } \\
\text { find out how to satisfy employees. }\end{array}$ & 0.861 & 0.031 & 25.100 \\
\hline $\begin{array}{l}\text { Managers meet with employees regularly to find out the } \\
\text { expectations of their jobs. }\end{array}$ & 0.868 & 0.034 & 23.208 \\
\hline $\begin{array}{l}\text { The company surveys employees at least once a year to } \\
\text { assess the quality of employment. }\end{array}$ & 0.804 & 0.053 & 13.234 \\
\hline Managers respect employees' suggestions and remarks. & 0.791 & 0.031 & 26.120 \\
\hline \multicolumn{4}{|l|}{$\begin{array}{l}\text { Informal communication with superiors } \\
\text { Cronbach Alpha 0.899; C.R. 0.930; AVE } 0.768\end{array}$} \\
\hline $\begin{array}{l}\text { Our manager regularly talks to us to find out about our } \\
\text { work. }\end{array}$ & 0.868 & 0.030 & 27.656 \\
\hline $\begin{array}{l}\text { When our manager notices that we are acting differently } \\
\text { than usual, they will try to find out why. }\end{array}$ & 0.884 & 0.040 & 19.760 \\
\hline $\begin{array}{l}\text { Our manager tries to find out what we want from the com- } \\
\text { pany when at work. }\end{array}$ & 0.898 & 0.025 & 32.634 \\
\hline $\begin{array}{l}\text { Our manager tries to find out our real feelings about jobs } \\
\text { at work. }\end{array}$ & 0.854 & 0.043 & 17.888 \\
\hline \multicolumn{4}{|l|}{$\begin{array}{l}\text { Communication with colleagues } \\
\text { Cronbach Alpha 0.937; C.R. 0.939; AVE } 0.654\end{array}$} \\
\hline I'm happy with the communication with my colleagues. & 0.761 & 0.053 & 14.602 \\
\hline I enjoy open communication with my colleagues. & 0.775 & 0.049 & 15.719 \\
\hline The information I obtain from colleagues is reliable. & 0.773 & 0.045 & 16.969 \\
\hline My colleagues always listen carefully when I address them. & 0.845 & 0.024 & 36.264 \\
\hline My colleagues always understand what I want to say. & 0.861 & 0.031 & 25.830 \\
\hline $\begin{array}{l}\text { In my workplace, internal communication with colleagues } \\
\text { encourages productivity. }\end{array}$ & 0.810 & 0.024 & 35.716 \\
\hline $\begin{array}{l}\text { Internal communication with colleagues at my workplace } \\
\text { affects guest satisfaction. }\end{array}$ & 0.864 & 0.062 & 11.890 \\
\hline $\begin{array}{l}\text { Communicating with colleagues is essential to the well- } \\
\text { being of my organization. }\end{array}$ & 0.741 & 0.062 & 11.210 \\
\hline $\begin{array}{l}\text { I consider that my colleagues consider my opinions, sug- } \\
\text { gestions, and ideas. }\end{array}$ & 0.865 & 0.024 & 36.456 \\
\hline
\end{tabular}

The outer loadings for one indicator in the Job satisfaction factor were less than 0.4 , so it was eliminated (Table 2). 


\begin{tabular}{|c|c|c|c|}
\hline \multicolumn{4}{|l|}{$\begin{array}{l}\text { Job satisfaction } \\
\text { Cronbach Alpha 0.930; C.R. 0.936; AVE } 0.507\end{array}$} \\
\hline $\begin{array}{l}\text { I'm satisfied with the amount and quality of information } \\
\text { I get about the strategy and purpose of the company's } \\
\text { business. }\end{array}$ & 0.726 & 0.040 & 18.019 \\
\hline $\begin{array}{l}\text { I am more likely to get information from a manager related } \\
\text { to their actions, achievements, and successes than a col- } \\
\text { league. }\end{array}$ & 0.716 & 0.035 & 20.680 \\
\hline $\begin{array}{l}\text { I get enough information on whether I am doing my job } \\
\text { correctly. }\end{array}$ & 0.749 & 0.034 & 22.561 \\
\hline My superior listens to me when I talk to them. & 0.688 & 0.052 & 13.375 \\
\hline I'm happy with the information flow in the company. & 0.782 & 0.271 & 1.019 \\
\hline I get feedback on how I'm doing my job. & 0.729 & 0.046 & 16.106 \\
\hline I follow the news of the company I work for. & 0.676 & 0.050 & 13.164 \\
\hline The information I receive from my supervisor is reliable. & 0.672 & 0.055 & 12.162 \\
\hline $\begin{array}{l}\text { My knowledge and talents have been sufficiently utilized } \\
\text { in this workplace. }\end{array}$ & 0.661 & 0.064 & 10.281 \\
\hline I receive acknowledgments for my work. & 0.662 & 0.052 & 12.911 \\
\hline $\begin{array}{l}\text { I have all the materials and equipment I need to do the job } \\
\text { I'm doing. }\end{array}$ & 0.672 & 0.056 & 12.328 \\
\hline I'm happy with the job I'm doing. & 0.713 & 0.044 & 16.496 \\
\hline I'm satisfied with the support I receive from the company. & 0.768 & 0.030 & 25.928 \\
\hline $\begin{array}{l}\text { I'm satisfied with the career opportunities I have in this } \\
\text { company. }\end{array}$ & 0.748 & 0.031 & 24.375 \\
\hline I'm happy with the relationship I have with my bosses. & 0.706 & 0.049 & 14.847 \\
\hline
\end{tabular}

The bootstrap procedure was based on 500 subsamples. The outer loadings of the constructs exceed the recommended value of 0.7 , except for one indicator in the construct 'Formal communication with superiors' and five indicators in the construct' Job satisfaction,' ranging from 0.6 to 0.7 . These values for manifest variables are considered acceptable in social sciences (Hair et al., 2013). The C.R. values are above the recommended 0.7 and range from 0.904 to
0.939. The AVE values are all above 0.5 and range from 0.507 to 0.768 . Therefore, internal consistency of reliability and convergent validity were tested (Hair et al., 2013).

Table 3 shows the heterotrait-monotrait ratio (HTMT) of the correlations used to assess discriminant validity. The HTMT ratio ranges from 0.492 to 0.783 , below the recommended threshold of 0.9 . 


\section{Journal of Contemporary Management Issues}

Table 3. Heterotrait-monotrait correlations

\begin{tabular}{|l|c|c|c|}
\hline & Satisfaction & $\begin{array}{c}\text { Informal } \\
\text { communication with } \\
\text { superiors }\end{array}$ & $\begin{array}{c}\text { Formal communication } \\
\text { with superiors }\end{array}$ \\
\hline Satisfaction & 0.685 & & \\
\hline $\begin{array}{l}\text { Informal communication with } \\
\text { superiors }\end{array}$ & 0.715 & 0.783 & \\
\hline $\begin{array}{l}\text { Formal communication with } \\
\text { management }\end{array}$ & 0.579 & 0.618 & 0.492 \\
\hline Communication with colleagues & & & \\
\hline
\end{tabular}

The measurement model results show a satisfactory level of discriminant validity and internal consistency of reliability.

\section{FINDINGS}

\subsection{Hypotheses testing}

The structural model's parameters statistical significance was established using the bootstrapping technique (500 sub-samples).

Table 4. Structural estimates

\begin{tabular}{|l|l|c|c|c|c|c|}
\hline & \multicolumn{1}{|c|}{ Hypotheses } & $\begin{array}{c}\text { Original sample- } \\
\text { standardized } \\
\text { coefficient }\end{array}$ & t-value & $\begin{array}{c}\mathbf{f}^{2}-\text { effect } \\
\text { size }\end{array}$ & $\mathbf{R}^{2}$ & $\begin{array}{c}\text { Accepted } \\
\text { hypotheses }\end{array}$ \\
\cline { 1 - 5 } H1 & $\begin{array}{l}\text { Communication with } \\
\text { superiors } \rightarrow \text { Satisfaction }\end{array}$ & 0.570 & 8.686 & 0.473 & \multirow{2}{*}{ Accepted* } \\
\cline { 1 - 4 } H2 & $\begin{array}{l}\text { Communication with } \\
\text { colleagues } \rightarrow \text { Satisfaction }\end{array}$ & 0.229 & 3.013 & 0.076 & \multirow{2}{*}{ Accepted** } \\
\hline
\end{tabular}

Table 4 shows the results of the structural model analysis.

$$
{ }^{* *} \mathrm{p}<0.05
$$

The analytical results indicate that communication with superiors (i.e., formal and informal) and colleagues influence employee satisfaction. In line with the model analysis, all the hypotheses are accepted. The construct of communication with superiors has a statistically significant positive effect on satisfaction ( $\beta=0.570 ;[0.240-0.834]$ ), as well as communication with colleagues on satisfaction $(\beta=0.229 ; \quad[0.008-0.223]$, $\mathrm{p}<0.05)$. Together they explain $52.7 \%$ of the variance, which is moderate. The $\mathrm{f}^{2}$ effect size of communication with superiors is 0.473 , which is considered, according to Cohen (1988), a large effect size, while communication with colleagues is 0.076, which can be regarded as a small effect size.

The standardized root mean square residual (SRMR) value was calculated to assess the quality of the structural model. Its value is 0.084 , indicating a sufficient 
structural model adjustment level to empirical data because it is below the recommended threshold of 0.1 .

\section{DISCUSSION AND CONCLUSION}

The primary focus of this paper is to provide educators, managers, and all interested parties with an insight into the relationship between internal communication with superiors and colleagues and employee satisfaction. This study shows that both types of communication (communication with managers and colleagues) positively impact job satisfaction, with communication with superiors having a more significant impact, explaining the largest amount of variance. Contrary to the dominant research area that analyzes the manager perception of internal communication (Ruck and Welch, 2012; Marques, 2010) and employee engagement (Wiley et al., 2010; Tkalac Verčič and Pološki Vokić, 2017), we assessed internal communication with superiors and colleagues with job satisfaction.

Previous research, conducted in different environments and under other conditions, has proved that employee satisfaction depends on communication within an organization. Yang (2015) finds conversation an essential medium in internal communication, while Dasgupta et al. (2012) noted the importance of managers in employee satisfaction, where communication plays an important role. Chen and Cheng (2012) find internal communication an essential way of exchanging knowledge, sharing information, and ensuring that employees perceive themselves as part of the organization. Wang's (2012) research of the hotel chain has confirmed that the quality of internal communication has a positive and significant impact on workers' satisfaction in international tourism hotels. Prikshat et al. (2020) explored the influence of transformational leadership on follower growth satisfaction through follower interpersonal communication satisfaction and trust in the hospitality industry. A positive relationship was found between interpersonal communication and growth satisfaction in the job. However, no study has identified the difference between communication with superiors and colleagues to the best of the authors' knowledge.

In line with Gomes, Fernandes, and Sobreira (2011), who found that internal communication is essential in keeping employees connected with the organization, this survey explains the importance of communication in achieving employee job satisfaction. Similarly, the results confirm similar prior research, which found evidence regarding interpersonal communication and job satisfaction (Vermeir et al., 2018; Malik, 2011).

\subsection{Practical implications}

In the $21^{\text {st }}$ century, managers should search for ways to attract and retain good employees, where employee satisfaction plays a key role. One of the challenges for all organizations, particularly in the hospitality industry, will be managing and retaining different generations to work together and achieve satisfaction with the same leadership or management approach.

In a setting with open communication, interaction, discussion, and consultation among employees are possible, thus facilitating the organization's sharing of knowledge and empowerment. In this way, employers can improve their communication skills, and employees can enjoy better work communication, which leads to greater work satisfaction. 


\section{Journal of Contemporary Management Issues}

Regular improvements in internal communication make employees more efficient and increase the likelihood that they will relate to the job with dedication and passion. The feeling that their contribution is appreciated increases the motivation and desire for constant progress. Satisfied employees create an environment that is desirable to work in and increases the company's competitive advantage, which should be the common mission of all businesses.

Managers' and employees' communication skills need to be constantly improved, as the ability to communicate efficiently is indispensable in the hotel business. Understanding communication skills are fundamental to personal and social development through constant interaction with the environment. Therefore, organizations in the hospitality industry can facilitate internal communication using various internet platforms, apps, and other communication technologies. Facilitating communication upward, employees will share confidential and operational information with superiors and colleagues.

\subsection{Research limitations}

The limitations of this study offer opportunities for future research. Although a national sample was used in this research, its implications and results may be valuable for researchers in other tourist countries. It would also be interesting to test whether there are any differences in responses if the survey was conducted outside the hotel. That could contribute to a more open atmosphere of dialogue and sincerity in the answers. Future studies can innovate the research methodology to avoid the employees' self-reports, raising concerns about self-serving bias.

It will be helpful for future studies to reduce problems arising from potential common-method bias by using multiple data sources and larger samples. Further research could include the influence of ICT in communication with both superiors and colleagues and the variables moderating the relationship between communication and satisfaction, which the present paper did not examine.

By establishing successful communication with superiors and colleagues for job satisfaction, future research could explore new dimensions of colleagues' motivation, support, and information trust, according to informal and formal interpersonal communication. Due to the competitive environment in the hospitality industry and arising importance of internal communication, future studies can include large measures and sub-factors of the presented factors to advance this area of research.

\section{REFERENCES}

1. Agušaj, B. and Čuić Tanković, A. (2016). The relationship between employee intention to quit and perceived corporate reputation in user-generated content in hotel industry. Conference Proceedings of the International Scientific Conference, University Juraj Dobrila, Pula, 183-192.

2. Al Eslami Kandlousi, N.S., Ali, A.J. and Abdollahi, A. (2010). Organizational Citizenship Behavior in Concern of Communication Satisfaction: The Role of the Formal and Informal Communication. International Journal of Business and Management, 5(10), 51-61.

3. Antolović, K. and Sviličić N. (2016). Interpersonal communication. $\mathrm{K} \& \mathrm{~K}$ Promocija, Zagreb

4. Baeza, M. A., Gonzalez, J. A. and Wang, Y. (2018). Job flexibility and 
job satisfaction among Mexican professionals: a socio-cultural explanation. Employee Relations, 40(5), 921-942.

5. Bamporiki, A. (2010). The impact of internal communication on guest satisfaction in hospitality establishments in Cape Town. Faculty of Business at the Cape Peninsula University of Technology, Master thesis

6. Bartle, J. and Griffiths, D. (2001). Power as well as Persuasion: political communication and Party development. available at: https://dspace.lboro. ac.uk/dspace-jspui/handle/2134/1093 (accessed 07 February 2019)

7. Blau, P. (1964). Power and exchange in social life. $J$ Wiley \& Sons, United States of America.

8. Bolfek B., Milković V., Lukavac, M. (2017). Influence of internal communication to satisfaction of employee at a workplace, Oeconomica Jadertina, 7(1), 16-27.

9. Borca, C. and Baesu, V. (2014)., A Possible Managerial Approach for Internal Organizational Communication Characterization. Procedia - Social and Behavioral Sciences, 124, 496-403.

10. Bovée, C.L. and Thill J.V. (2012). Contemporary business communication. MATE d.o.o., Zagreb

11. Carpenter, M. A., Bauer, T., Erdogan, B. and Short, J. (2010). Principles of management. Flat World Knowledge

12. Chen, W.J. and Cheng, H.Y. (2012). Factors affecting the knowledge sharing attitude of hotel service personnel. International Journal of Hospitality Management, 31(2), 468-476.

13. Cummings, HW, Long, LW, \& Lewis, ML (1983). Managing communication in organizations: An introduction. Dubuque, Gorsuch-Scarisbrick.
14. Cushman, D.P., and Cahn, D.D.Jr. (1985). Communication in Interpersonal Relationships. State University of New York Press, Albany

15. Dasgupta, S. A., Suar, D. and Singh, S. (2012). Impact of managerial communication styles on employees' attitudes and behaviours. Employee Relations, 35(2), 173-199.

16. De Chernatony, L., Cottam, S. and Segal-Horn, S. (2006). Communicating services brands' values internally and externally. The Service Industries Journal, 26(8), 819-836.

17. Diamantopoulos, A. (2011). Incorporating formative measures into covariance-based structural equation models. MIS Quarterly, 35(2), 335-358.

18. Diamantopoulos, A. and Winklhofer, H.M. (2001). Index construction with formative indicators: an alternative to scale development. Journal of Marketing Research, 38(2), 269-277.

19. Downs, C. W. and Hazen, M. D. (1977). A factor analytic study of communication satisfaction. The Journal of Business Communication, 14(3), 63-73.

20. Eisenberg, E.M., Goodall H.L.Jr. and Trethewey A. (2010). Organizational communication: Balancing Creativity and Constraint. Bedford St. Martins, Boston

21. Eisenberger, R., Huntington, R., Hutchison, S. and Sowa, D. (1986). Perceived organizational support. Journal of Applied Psychology, 71(3), 500-507.

22. Gomes, D.R., Fernandes, J.L. and Sobreira, R.M.C. (2011). Promoting a path for organizational competitiveness: the role of internal communication. Exedra: Revista Cientifica, 1, 55-78. 


\section{Journal of Contemporary Management Issues}

23. Gray, J. and Laidlaw, H. (2002). Parttime employment and communication satisfaction in an Australian retail organization. Employee Relations, 24(2), 211-228.

24. Grzinic, J. (2008). Trends in Croatian hotel industry. Management and Marketing Journal, 6(1), 122-128.

25. Hair, J.F. Jr, Hult, G.T.M., Ringle, C. and Sarstedt, M. (2013). A Primer on Partial Least Squares Structural Equation Modeling (PLS-SEM). Sage Publications, Thousand Oaks

26. Henseler, J. and Sarstedt, M. (2013). Goodness-of-fit indices for partial least squares path modelling. Computational Statistics, 28(2), 565-580.

27. Hu, E., Zhang, M., Shan, H., Zhang, L. and Yue, Y. (2018). Job satisfaction and union participation in China: Developing and testing a mediated moderation model. Employee Relations, 40(6), 964-980.

28. Ingram, H. and Desombre, T. (1999). Teamwork: comparing academic and practitioners' perceptions. Team Performance Management: An International Journal, 5(1), 16-22.

29. Jabeen, F. and Isakovic, A. A. (2018). Examining the impact of organizational culture on trust and career satisfaction in the UAE public sector: A competing values perspective. Employee Relations, 40(6), 1036-1053.

30. Jarvis, C.B., MacKenzie, S.B. and Podsakoff, P.M. (2003). A critical review of construct indicators and measurement model misspecification in marketing and consumer research. Journal of Consumer Research, 30(2), 199-218.

31. King, C. (2010). One size doesn't fit all: Tourism and hospitality employees' response to internal brand management. International Journal of Contemporary Hospitality Management, 22(4), 517-534.

32. Koontz, H., O`Donnell C. and Weihrich, H. (1980). Management: A Book of Readings. Anybook Ltd., United Kingdom

33. Kraljević, R., Perkov D. (2014). Communication management marketing. Libertas - Plejada, Zagreb

34. Lahap, J., O'Mahony, B. and Dalrymple, J. (2016). The importance of communication in improving service delivery and service quality in the Malaysian hotel industry. ProcediaSocial and Behavioral Sciences, 224, 213-220.

35. Lesikar, R.V., Pettit J.D. and Flatley M.E. (1993). Basic business communication. IRWIN, Burr Ridge.

36. Lunenburg, F.C. (2010). Communication: The Process, Barriers, And Improving Effectiveness. Schooling, 1(1), 1-11.

37. Malik, N. I. (2011). Level of job satisfaction among university and college men and women teachers. Interdisciplinary Journal of Contemporary Research in Business, 3(3), 750-758.

38. Marchington, M., \& Suter, J. (2013). Where informality really matters: Patterns of employee involvement and participation (EIP) in a non-union firm. Industrial Relations: A Journal of Economy and Society, 52, 284-313.

39. Marques, J. F. (2010). Enhancing the quality of organizational communication. Journal of Communication Management, 14(1), 47-58.

40. Miljković, D. and Rijavec, M. (2002). Communication in organization. IEP d.o.o., Zagreb 
41. Molina-Azorín, J. F., Claver-Cortés, E., Pereira-Moliner, J. and Tarí, J. J. (2009). Environmental practices and firm performance: an empirical analysis in the Spanish hotel industry. Journal of Cleaner Production, 17(5), 516-524.

42. Naim, M. F. and Lenka, U. (2018). Development and retention of Generation Y employees: a conceptual framework. Employee Relations, 40(2), 433-455.

43. Obushenkova, E., Plester, B. and Haworth, N. (2018). Manageremployee psychological contracts: enter the smartphone. Employee Relations, 40(2), 193-207.

44. Pende, H. (2013). Croatian Tourism - Identity Management. Hrvatska sveučilišna naknada, Zagreb

45. Perinić, J. (2008). Business communication paradigm. Sveučilišna knjižara d.o.o., Zagreb

46. Plester, B. and Hutchison A. (2016). Fun times: the relationship between fun and workplace engagement. Employee Relations, 38(3), 332-350.

47. Politis, Y., Litos, C., Grigoroudis, E. and Moustakis, V.S. (2009). A business excellence model for the hotel sector: implementation to high-class Greek hotels. Benchmarking: An International Journal, 16 (4), 462-483.

48. Prikshat, V., Rajesh, J. I., and Rajaguru, R. (2020). The growth satisfaction in jobs among hospitality employees: the role of transformational leadership, interpersonal communication satisfaction and trust. Journal of Human Resources in Hospitality \& Tourism, 1-27

49. Reinartz, W., Haenlein, M. and Henseler, J. (2009). An empirical comparison of the efficacy of covariance-based and variance-based SEM.
International Journal of Research in Marketing, 26(4), 332-344.

50. Rossela, N. and Stoica, I. (2012). Internal communication - a prerequisite for organizational effectiveness. Holistic Marketing Management Journal, 2(3), 45-50.

51. Ruck, K., \& Trainor, S. (2012). Developing internal communication practice that supports employee engagement. 1-25. Retrieved from: http://www.pracademy. co.uk/wpcontent/uploads/2012/07/ Developing-Internal-CommunicationPractice-That-Supports-EmployeeEngagement-July-2012.pdf

52. Ruck, K., and Welch, M. (2012). Valuing internal communication; management and employee perspectives. Public Relations Review, 38(2), 294-302.

53. Ruiz-Alba, J., Bermúdez-González, G., Rodríguez-Molina, M.A. and Blanca, M.J. (2014). Internal Marketing Orientation: an empirical research in hotel sector. International Journal of Hospitality Management, 38, 11- 19.

54. Saks, A.M. (2006). Antecedents and consequences of employee engagement. Journal of Managerial Psychology, 21(6), 600-19.

55. Silva, P. (2006). Effects of disposition on hospitality employee job satisfaction and commitment. International Journal of Contemporary Hospitality Management, 18(4), 317-328.

56. Steyn, E., Steyn, T.F.J. and van Rooyen, M. (2011). Internal communication at DaimlerChrysler South Africa: A qualitative perspective on two-way symmetrical communication and internal marketing. Journal of Marketing Development and Competitiveness, 5(4), 131-144. 


\title{
Journal of Contemporary Management Issues
}

57. Tews, M. J., Michel, J., Xu, S. and Drost, A. J. (2015). Workplace fun matters...but what else? Employee Relations, 37(2), 248-267.

58. Tixier, M. (1994). Management and Communication Styles in Europe: Can They Be Compared and Matched. Employee Relations, 16(1), 8-26.

59. To, W. M., Martin Jr, E. F. and Billy, T. W. (2015). Effect of management commitment to internal marketing on employee work attitude. International Journal of Hospitality Management, $45,14-21$.

60. Townsend, K., Wilkinson, A., and Burgess, J. (2013). Filling the gaps: Patterns of formal and informal participation. Economic and Industrial Democracy, 34(2), 337-354.

61. Verčič, A. T., and Vokić, N. P. (2017). Engaging employees through internal communication. Public Relations Review, 43(5), 885-893.

62. Vermeir, P., Downs, C., Degroote, S., Vandijck, D., Tobback, E., Delesie, L., Vogelaers, D. (2018).
Intraorganizational communication and job satisfaction among Flemish hospital nurses: An exploratory multicenter study. Workplace Health \& Safety, 66(1), pp. 16-23.

63. Wang, G.L. (2012). The influence of internal service quality on employee job satisfaction at Taiwan-listed international tourist hotels: using organisational culture as the moderator. World Transactions on Engineering and Technology Education, 10(3), 174-183.

64. Wiley, J. W., Kowske, B. J., and Herman, A. E. (2010). Developing and validating a global model of employee engagement. in: Albrecht, S. L. (Ed.): Handbook of employee engagement: Perspectives, issues, research and practice, Edward Elgar Publishing, 351-363.

65. Yang, J.T. (2015). Effect of internal marketing on knowledge sharing and organisational effectiveness in the hotel industry. Total Quality Management \& Business Excellence, 26(1-2), 76-92.

\section{INTERNA KOMUNIKACIJA I ZADOVOLJSTVO ZAPOSLENIKA U HOTELIJERSTVU}

\begin{abstract}
Sažetak
Svrha ovog rada je istražiti utjecaj interne komunikacijena zadovoljstvo zaposlenika u hotelijerstvu, s aspekata komunikacije s menadžerima i kolegama.. Prikupljanje podataka je provedeno na uzorku zaposlenika dvaju hotelskih objekata - članova istog hotelskog lanca, s jednakom kategorizacijom. Primjenom metode strukturnih

jednadžbi (PLS-SEM), rezultati istraživanja ukazuju na to da obje vrste komunikacije pozitivno utječu na zadovoljstvo zaposlenika.

Ključne riječi: zadovoljstvo poslom, komunikacija s nadređenima, komunikacija s kolegama, hotelijerstvo
\end{abstract}

